\title{
Relative growth, sexual maturity and handedness in the ghost shrimp Callichirus major (Decapoda: Callianassidae) from the southwestern Atlantic
}

\author{
Juliana Priscila Piva Rio 1,2, Patricio Hernáez ${ }^{1,3}$, Marcelo Antonio Amaro Pinheiro 1,2 \\ ${ }^{1}$ Universidade Estadual Paulista (UNESP), Instituto de Biociências (IB), Câmpus do Litoral Paulista (CLP), \\ Grupo de Pesquisa em Biologia de Crustáceos (CRUSTA), Praça Infante Dom Henrique, s/n, Parque Bitaru, 11330-900, \\ São Vicente, SP, Brazil. \\ (JPPR) (Corresponding author) E-mail: julianario.bio@ gmail.com. ORCID iD: https://orcid.org/0000-0002-8195-3596 \\ (PH) E-mail: pahernaez@ gmail.com. ORCID iD: https://orcid.org/0000-0002-3785-2050 \\ (MAAP) E-mail: marcelo.pinheiro@unesp.br. ORCID iD: https://orcid.org/0000-0003-0758-5526 \\ ${ }^{2}$ Programa de Pós-graduação em Biodiversidade Aquática (PPGBA), UNESP IB/CLP. \\ ${ }^{3}$ Universidad de Tarapacá (UTA), Facultad de Ciencias, Centro de Estudios Marinos y Limnológicos, Av. General Ve- \\ lásquez 1775, Arica, Chile.
}

\begin{abstract}
Summary: Biometric studies provide valuable information about changes associated with the growth and sexual maturity of living organisms. We analysed sexual dimorphism, allometric growth, sexual maturity and handedness in the ghost shrimp Callichirus major at Gonzaga beach, Brazil, where the catches of this species have been prohibited since 1992 . To this end, a total of 544 individuals of $C$. major were collected during 12 months of sampling. Males were significantly smaller than females, denoting sexual dimorphism with respect to body size. The analysis of allometric growth between chelar carpus length and carapace length (CL) revealed a positive allometric relationship in juveniles of both sexes and adult males, but a negative allometry in adult females. Overall, our results showed the existence of two main growth phases related to sexual maturity, with a similar transition point for males $(15.0 \mathrm{~mm} \mathrm{CL})$ and females $(16.0 \mathrm{~mm} \mathrm{CL})$. Heterochely and homochely were registered in shrimp from both sexes, but in males heterochely occurred to a higher degree and was predominant $(86.9 \%)$, whereas in females homochely was slightly more frequent $(59.3 \%)$. The consequences of sexual dimorphism in terms of body size and chelipeds in the mating system of $C$. major are discussed in this study.
\end{abstract}

Keywords: Axiidea; Brazil; chelar morphometry; Crustacea; population biology; sexual dimorphism.

Crecimiento relativo, madurez sexual y heteroquelia en el camarón fantasma Callichirus major (Decapoda: Callianassidae) del Atlántico sur occidental

Resumen: Los estudios biométricos proporcionan valiosa información sobre los cambios asociados al crecimiento y la madurez sexual de los organismos. En este estudio, se analizó el dimorfismo sexual, el crecimiento alométrico, la madurez sexual y la heteroquelia en el camarón fantasma Callichirus major procedente de la playa de Gonzaga (Brasil), en donde las capturas de esta especie están prohibidas desde 1992. Para este propósito, fueron colectados 544 ejemplares de $C$. major durante 12 meses de muestreos. Los machos fueron significantemente más pequeños que las hembras, lo cual denotó el dimorfismo sexual con respecto al tamaño corporal. El análisis del crecimiento alométrico entre la longitud del carpo quelar (CCL) y la longitud del caparazón (CL) reveló una relación alométrica positiva en los juveniles de ambos sexos y los machos adultos, y una alométrica negativa en las hembras adultas. En general, nuestros resultados mostraron la existencia de dos fases de crecimiento relacionadas con la madurez sexual separadas por un punto de transición similar para los machos (15,0 $\mathrm{mm} \mathrm{CL})$ y hembras (16,0 mm CL). Se observó heteroquelia y homoquelia en los especímenes de ambos sexos. Sin embargo, en los machos predominó $(86,9 \%)$ sobre la homoquelia, mientras que en las hembras esta última fue ligeramente más frecuente $(59,3 \%)$. Finalmente, en este estudio se discuten las consecuencias del dimorfismo sexual en términos del tamaño corporal y de los quelípedos sobre el sistema de apareamiento de C. major.

Palabras clave: Axiidea; Brasil; morfometría quelar; Crustacea; biología de la población; dimorfismo sexual.

Citation/Como citar este artículo: Rio J.P.P., Hernáez P., Pinheiro M.A.A. 2019. Relative growth, sexual maturity and handedness in the ghost shrimp Callichirus major (Decapoda: Callianassidae) from the southwestern Atlantic. Sci. Mar. 83(2): 167-175. https://doi.org/10.3989/scimar.04869.28A

Editor: J.A. Cuesta.

Received: October 1, 2018. Accepted: March 18, 2019. Published: May 16, 2019.

Copyright: () 2019 CSIC. This is an open-access article distributed under the terms of the Creative Commons Attribution 4.0 International (CC BY 4.0) License. 


\section{INTRODUCTION}

In function of their feeding and behavioural interactions, crustaceans may have specialized claws as a first pair of pereopods (Mariappan et al. 2000). Hartnoll $(1974,2012)$ mentions a chelar difference (heterochely) in most decapod crustaceans, generally more pronounced in males, which use it in agonistic interactions related to territorial defence or during competition for sexual partners. During post-larval development, decapods can display body changes with the onset of the secondary sexual characters, generating two phases (juvenile and adult) better described by a power function $(\mathrm{Y}=\mathrm{aX}$ ) and separated by a critical moult (puberty moult) (Huxley 1950, Hartnoll 1974). According to Hartnoll (1982), when a dependent variable (e.g. claw size or abdominal article) is related to an independent variable (e.g. body size), growth rate can be obtained by allometric coefficient (' $b$ ' constant), generating an isometry $(b=1)$ or allometry (positive $b>1$ and negative $b<1)$. Such growth patterns are specific to each species and vary as a function of development phase of each sex (juvenile and adult), generating two discontinuous phases of growth and consequently two different levels of allometric coefficients that define the moment of the morphological sexual maturity in decapods (Pinheiro and Fransozo 1998, Pardal-Souza and Pinheiro 2013).

Heterochely, here defined as different-sized chelipeds, is a common attribute in most decapods (e.g. Aegla franca Schmitt, 1942: Bueno and Shimizu 2009; Alpheus brasileiro Anker, 2012: Pescinelli et al. 2018; Platyxanthus crenulatus [Milne-Edwards, 1879]: Laitano et al. 2013), including members of the family Callianassidae Dana, 1852 (collectively known as ghost shrimps). Adult males of callianassids invariably develop one hypertrophied cheliped (heterochely), while females and juveniles have subequal or homochelous chelipeds (Hernáez 2018 and references therein). The handedness or laterality, i.e., the tendency for the major cheliped to appear on a particular side of the body, has been poorly studied in these species. A recent study in the callianassid shrimp Callichirus seilacheri (Bott, 1955) demonstrated that the larger chelipeds in adult males develop independently on either the right or left side of the body (Hernáez and João 2018).

The intertidal ghost shrimp Callichirus major (Say, 1818 ) is a conspicuous species on many sandy beaches of the western Atlantic (Felder 2001). Its geographical distribution covers from North Carolina, USA, to Santa Catarina, Brazil (Hay and Shore 1918, Melo 1999). These animals build burrows in sediments, normally inhabited by only one shrimp (Rodrigues 1976). In the adult phase, the males of $C$. major are considered heterochelic due to an expressive claw difference in size/ shape (Rodrigues 1971, 1985, Manning and Felder 1986), but in juveniles and females the chelipeds are "subtly unequal" or considered homochelic (Rodrigues 1971). Chelar types in $C$. major have not been investigated and reported in detail.

Rodrigues (1985) first examined the chelar growth pattern of $C$. major from the Bay of Santos, in the southeastern region of Brazil, based on the relationship between propodus length (PL) and carapace length (CL), finding a negative allometry in juveniles of both sexes and adult females, with a dimorphic pattern and positive allometry in adult males. Subsequently, Alves-Júnior et al. (2014) reported a positive allometry through this species's ontogeny with this same relationship, confirming a higher chelar growth in males than in females for a population of C. major from Recife, in the northeastern region of Brazil, a fact explained by the thermal regime promoted by latitudinal influence. Both of these studies considered the growth of a chelar article that reaches a smaller size than the carpus, a noteworthy characteristic in species of the genus $\mathrm{Cal}$ lichirus Stimpson, 1866 (Manning and Felder 1986, Hernáez et al. 2015, Hernáez and João 2018). Another recent contribution by Alves-Júnior et al. (2018) indicated that the whole cheliped in $C$. major grows at a higher rate than the carapace, especially for males. It is important to highlight that Hartnoll $(1974,1978)$ recommends the use of biometric variables resulting from a more prominent chelar article (dependent variable) to estimate the morphological maturity size in males, generally represented by chelar propodus variables.

Furthermore, considering the intense harvest suffered by $C$. major as bait for recreational fishing in several Brazilian regions (Rodrigues and Shimizu 1997, Souza and Borzone 2003, Hernáez et al. 2019), the population of this species often fails to maintain its natural structure and a better representation in size classes. We therefore estimated the chelar relative growth and morphological maturity sizes in $C$. major, using a more reliable biometric variable (carpus size) and based on specimens captured in a stable and well-balanced population protected by law (see Ordinance \#850/1992) in Santos Municipality, Brazil. The patterns of handedness in this species were also determined in function of sex through the ontogeny.

\section{MATERIALS AND METHODS}

\section{Sampling and material processing}

Specimens of $C$. major (Fig. 1A) were collected monthly (from March 2016 to February 2017) from the intertidal zone, at Gonzaga beach $\left(23^{\circ} 58^{\prime} 13^{\prime \prime} \mathrm{S}\right.$, $\left.46^{\circ} 20^{\prime} 04^{\prime \prime} \mathrm{W}\right)$, Santos (SP), southeast coast of Brazil (Fig. 1B). Then, ghost shrimps were randomly collected from burrows with a hand-made "yabbie" pump (diameter $=77 \mathrm{~mm}$, length $=100 \mathrm{~cm}$ ). Therefore, to obtain a representative monthly sample size we inspected all visible burrowing holes. After shrimp collection, each specimen was carefully rinsed with seawater, placed in a plastic bag and transported for further analysis in the laboratory. Part of the material analysed in this study was deposited in the Crustacean Biology Research Group (CRUSTA) collection, of UNESP IB/ CLP (CRUSTA 160058).

In the laboratory, each specimen was sexed according to the morphology of the first pair of pleopods (bi-segmented in males; tri-segmented in females; Rio 2018), following the methodology proposed by Hernáez et al. (2018) for other American species of 


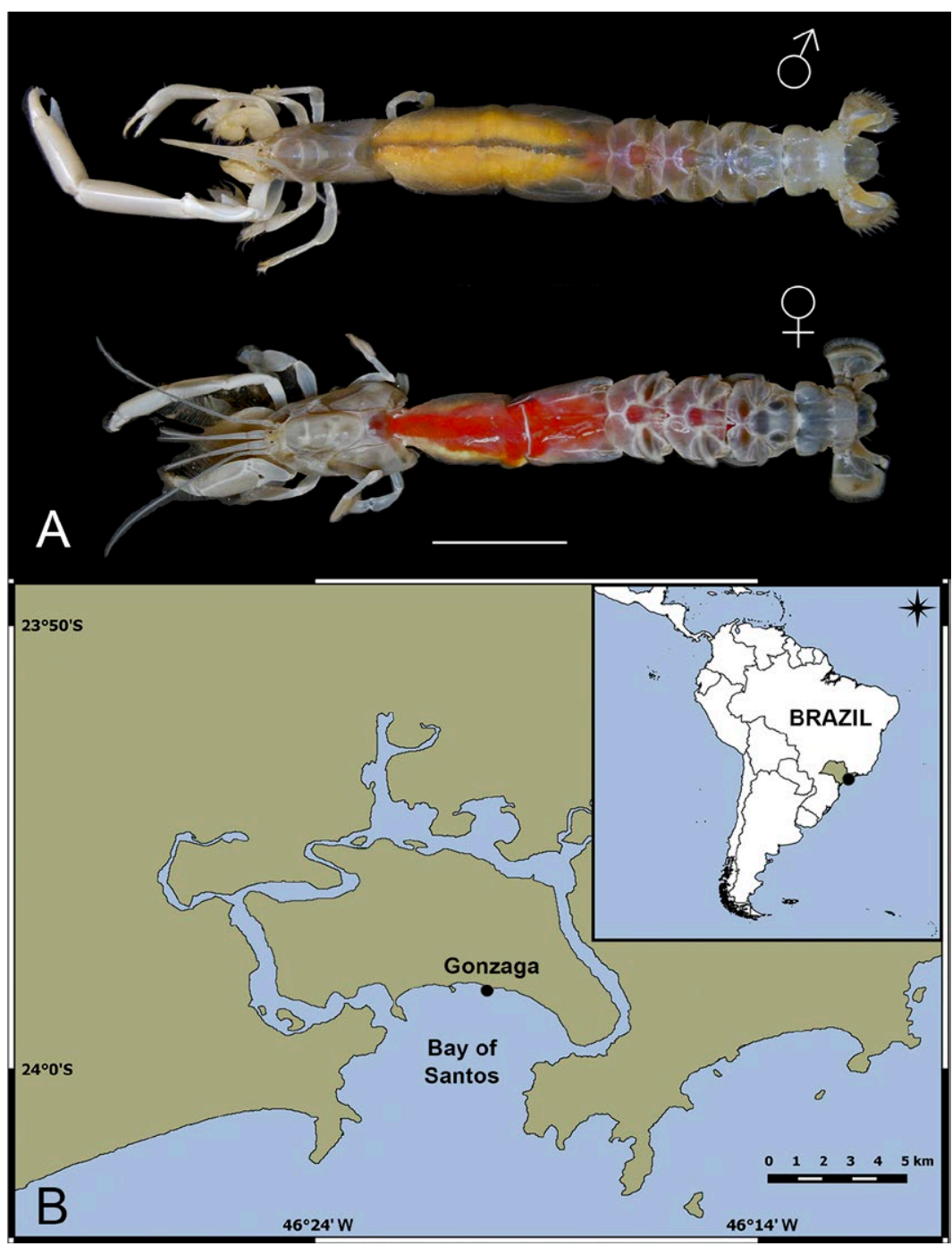

Fig. 1. - Dorsal view of male and female individuals of the ghost shrimp C. major (A). Geographical position of the study area (B). Scale bar $=1 \mathrm{~cm}$.

Callichirus. The shrimps were measured under a Zeiss Stemi SV-6 stereomicroscope equipped with an image analysis system (Zeiss AxioCam MRc5) (Carl Zeiss, Oberkochen, Germany) to record the CL (from postorbital margin to posterior median region of carapace), right and left chelar carpus length (CCL, between the articulations of the merus and propodus), and chelar carpus height $(\mathrm{CCH}$, between the dorsal and ventral margin, measured in the mid of the article) (Fig. 2).

\section{Sexual dimorphism}

The occurrence of sexual dimorphism in $C$. major was evaluated by comparing biometric variable values (CL, CCL and CCH) between sexes using a $t$-test (Sokal and Rohlf 2003), since distribution was normal and variances of the two groups being compared $(\alpha=$ 0.05 ) were homogenous.

\section{Relative growth and morphological maturity}

Carpus measures (CCL and $\mathrm{CCH}$ ) were used as dependent variables, each one related to $\mathrm{CL}$, which

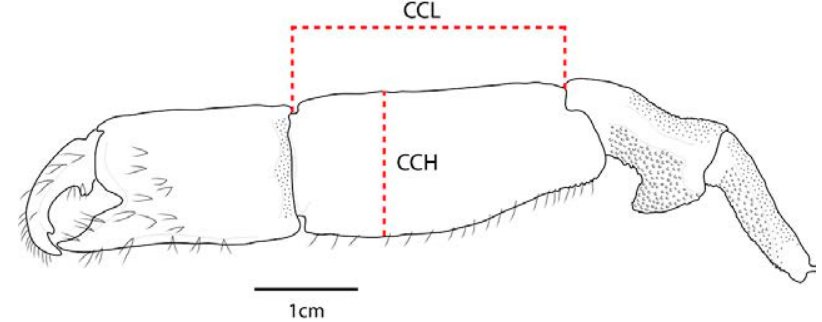

Fig. 2. - Male major cheliped used for appendicular measurements and relative growth analyses. $\mathrm{CCH}$, carpus height; CCL, carpus length.

was considered an independent variable (body size). So, the relative growth and morphological maturity of $C$. major were estimated according to two biometric relationships (CCL vs. CL and $\mathrm{CCH}$ vs. CL), always considering the measurements of both chelipeds. Data obtained for each biometric relationship were fitted by a power function $\mathrm{Y}=\mathrm{aX} \mathrm{X}^{\mathrm{b}}$ (Huxley 1950, Hartnoll 1974), followed by mathematical procedures indicated by Somerton (1980) and Somerton and Macintosh (1983), to estimate the size at onset of maturity in males and females, using the 
Table 1. - Callichirus major (Say, 1818). Regression analyses and relative growth pattern (RGP) involving variables measured in the carpus of the major cheliped (CPH, height; CPL, length) in relation to body size (CL, carapace length) of each sex and development phase (juvenile and adult). N, number of individuals; JM, juvenile males; AM, adult males; TM, total males; JF, juvenile females; AF, adult females; TF, total females; +, positive allometry; -, negative allometry). $* \mathrm{P}<0.01$.

\begin{tabular}{|c|c|c|c|c|c|c|}
\hline Biometric Relation & Sex/Phase & $\mathrm{N}$ & Power Function $\left(\mathrm{Y}=\mathrm{a} \mathrm{X}^{\mathrm{b}}\right)$ & $\mathrm{R}^{2}(\%)$ & RGP & t-test* \\
\hline CPL vs. CL & $\begin{array}{l}\mathrm{JM} \\
\mathrm{AM} \\
\mathrm{TM} \\
\mathrm{JF} \\
\mathrm{AF} \\
\mathrm{TF}\end{array}$ & $\begin{array}{c}44 \\
87 \\
131 \\
56 \\
247 \\
303\end{array}$ & $\begin{array}{l}\mathrm{CPL}=0.062 \mathrm{CL}^{2.02} \\
\mathrm{CPL}=0.310 \mathrm{CL}^{1.42} \\
\mathrm{CPL}=0.1015 \mathrm{CL}^{1.82} \\
\mathrm{CPL}=0.390 \mathrm{CL}^{1.22} \\
\mathrm{CPL}=4.584 \mathrm{CL}^{0.34} \\
\mathrm{CPL}=0.951 \mathrm{CL}^{0.87}\end{array}$ & $\begin{array}{l}82.5 \\
35.2 \\
85.8 \\
87.8 \\
10.8 \\
74.0\end{array}$ & $\begin{array}{l}+ \\
+ \\
+ \\
+ \\
- \\
-\end{array}$ & $\begin{array}{c}7.10 \\
2.02 \\
1.83 \\
3.81 \\
-10.47 \\
-3.72\end{array}$ \\
\hline $\mathrm{CPH}$ vs. $\mathrm{CL}$ & $\begin{array}{l}\mathrm{JM} \\
\mathrm{AM} \\
\mathrm{TM} \\
\mathrm{JF} \\
\mathrm{AF} \\
\mathrm{TF}\end{array}$ & $\begin{array}{c}44 \\
87 \\
131 \\
55 \\
248 \\
303\end{array}$ & $\begin{aligned} \mathrm{CPH} & =0.053 \mathrm{CL}^{1.92} \\
\mathrm{CPH} & =1.152 \mathrm{CL}^{0.77} \\
\mathrm{CPH} & =0.161 \mathrm{CL}^{1.47} \\
\mathrm{CPH} & =0.198 \mathrm{CL}^{1.37} \\
\mathrm{CPH} & =5.735 \mathrm{CL}^{0.16} \\
\mathrm{CPH} & =0.6518 \mathrm{CL}^{0.91}\end{aligned}$ & $\begin{array}{c}83.0 \\
23.6 \\
83.9 \\
82.8 \\
2.1 \\
65.7\end{array}$ & $\begin{array}{l}+ \\
- \\
+ \\
+ \\
- \\
-\end{array}$ & $\begin{array}{c}6.95 \\
-2.32 \\
2.68 \\
5.63 \\
-9.88 \\
-3.99\end{array}$ \\
\hline
\end{tabular}

segmented package of the R software version 2.13.0 (R Core Team 2013). The constant "a" represents the intercept of the regression line on the y-axis, while the constant "b" represents the slope of the mathematic equation, and also the growth level of the dependent variable in relation to an independent one (isometry, $\mathrm{b}=1$; negative allometry, $\mathrm{b}<1$; positive allometry, b>1) (Hartnoll 1982). The fit of the regression line to data in each biometric relation was evaluated by a determination coefficient $\left(\mathrm{R}^{2}\right)$ based on logarithmic values of the variables. Student t-tests were employed to verify growth level, verifying the contrast of " $b$ " from unit, and the Snedecor F-test was used to confirm one or two growth regression lines (Sokal and Rohlf 2003, $\alpha=0.05$ ). Ghost shrimps with missing claws or limbs were excluded from the allometric analyses.

\section{Handedness and chelar types}

We explored whether the larger cheliped is carried at the right or left side of the body using a new methodology different from those commonly used in the literature (see Davanso et al. 2016 and references therein). For each specimen, a handedness ratio (HR) of the chelipeds was established on the basis of the variable CCL, using the division of the size of the right chelar carpus by the size of the left chelar carpus $(\mathrm{HR}=\mathrm{CCLR} / \mathrm{CCLL})$. Specimens were classified as homochelous $(\mathrm{HO}$, when $\mathrm{HR}=1)$ or heterochelous (HE, when $\mathrm{HR} \neq 1$ ), the latter emphasizing the handedness: right (RHE) or left (LHE) heterochely. To minimize misclassification, homochelous specimens were covered by the confidence interval represented by $0.90 \leq \mathrm{HR} \leq 1.10$, which confirmed a small difference between the right and left carpus sizes. With this classification, heterochelic specimens were recognized as right $(\mathrm{HR}>1.10)$ and left $(\mathrm{HR}<0.90)$ heterochelic. The heterochely level of each specimen was obtained by subtracting the largest from the smallest CCL value and the result was expressed as a percentage. The proportion of homo and heterochelous specimens was contrasted between males and females through the ontogeny, revealed by chi-square test $\left(\chi^{2}\right)$ on statistical significance level of $5 \%$.

\section{RESULTS}

\section{Statistical summary and sexual dimorphism}

A total of 544 specimens of $C$. major were collected during the study period, of which 162 (29.8\%) were males and $382(70.2 \%)$ females, including 166 ovigerous females. The first pleopod is sexually dimorphic from the juvenile to the adult phase of $C$. $m a$ jor, which favoured the sex determination of all collected specimens in this species. The overall sex ratio differed significantly from evenness (males:females $\left.=0.30: 1.00 ; \chi^{2}=88.97, \mathrm{p}<0.05\right)$. Males measured 8.2 to $20.5 \mathrm{~mm} \mathrm{CL}$ (mean $\pm \mathrm{sd}: 15.4 \pm 3.0 \mathrm{~mm}$ ) and females 7.3 to $25.1 \mathrm{~mm}$ CL $(17.5 \pm 2.9 \mathrm{~mm})$. Females, on average, were significantly larger than males $(\mathrm{t}=6.85$, $\mathrm{P}=2.6810^{-11}$ ), denoting an evident sexual dimorphism with respect to CL body size. Male CCL ranged from 4.7 to $23.8 \mathrm{~mm}(15.2 \pm 5.4 \mathrm{~mm})$, whereas female CCL ranged from 5.1 to $13.4 \mathrm{~mm}(11.7 \pm 1.9 \mathrm{~mm})$, being on average significantly greater in males than females $\left(\mathrm{t}=-9.92 ; \mathrm{P}=5.3410^{-21}\right)$. Inversely, $\mathrm{CCH}$ did not differ between males (2.8 to $13.3 \mathrm{~mm} ; 9.0 \pm 2.5 \mathrm{~mm}$ ) and females (2.9 to $10.9 \mathrm{~mm} ; 8.8 \pm 1.5 \mathrm{~mm})(\mathrm{t}=-1.19$; $\mathrm{P}=0.23$ ).

\section{Relative growth and morphological maturity}

The chelar carpus relationships (CCL vs. CL and $\mathrm{CCH}$ vs. $\mathrm{CL}$ ) showed some variations regarding the relative growth in different development phases for the two sexes (see juveniles and adults in Table 1), with two linear models better fitted in each case than in a single model.

A positive allometry was detected in the CCL vs. $\mathrm{CL}$ ratio through the ontogeny of males (Fig. 3A), with a higher slope in juveniles $\left(b=2.02 ; \theta=63.7^{\circ}\right)$ than in adults $\left(b=1.42 ; \theta=54.8^{\circ}\right)$, differing by $8.9^{\circ}$ between these regression lines. A different pattern was obtained in the $\mathrm{CCH}$ vs. CL ratio of males (Fig. 4A), where juveniles also grew in positive allometry $(b=1.92$; $\left.\theta=62.5^{\circ}\right)$, but in the adult phase the growth was classified as allometric negative $\left(b=0.77 ; \theta=37.6^{\circ}\right)$. In the latter case, the slope of log-regression lines was reduced by $24.9^{\circ}$, i.e. three times more than the biometric relationship CCL vs. CL. 


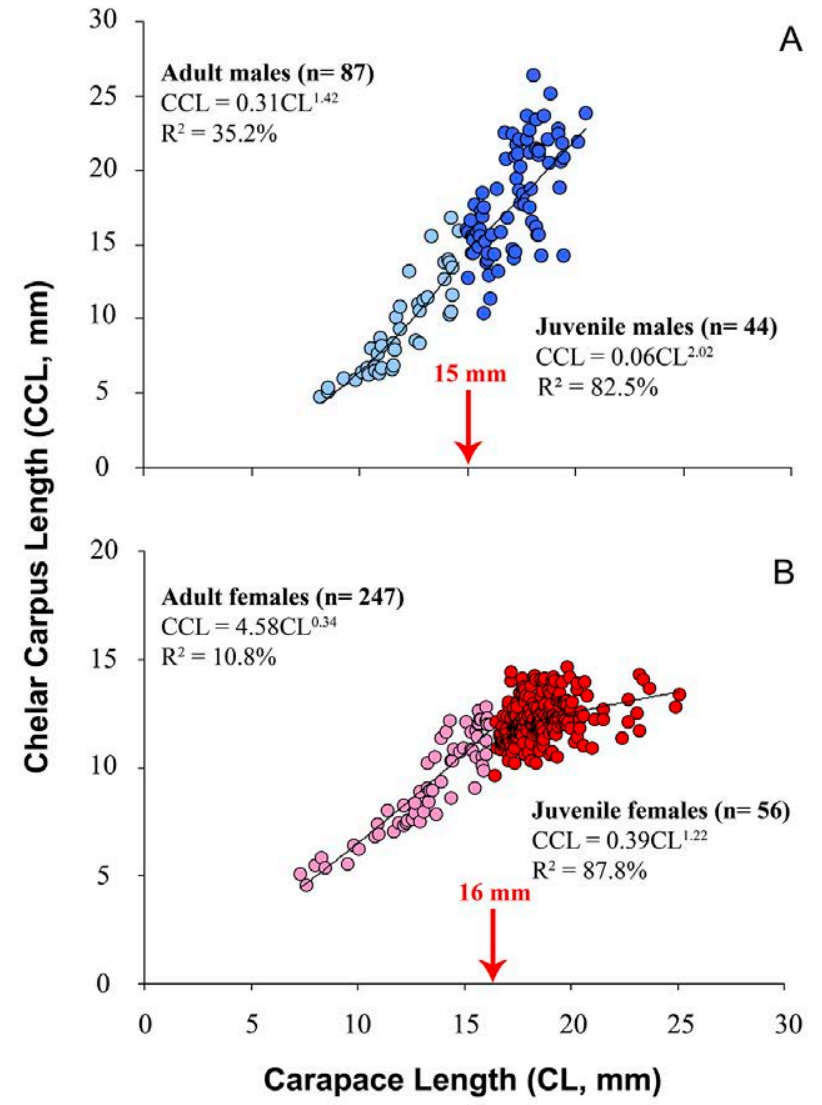

Fig. 3. - Biometric relationship CCL vs. CL, regression analyses of both development phases in males (A) and females (B), and size of morphological maturity. CCL, carpus length of the major cheliped;

CL, carapace length; light points, juveniles; dark points, adults.

In females, a positive allometric growth of the CCL vs. CL ratio $\left(b=1.22 ; \theta=50.7^{\circ}\right)$ was detected during the juvenile phase (Fig. 3B), changing to negative allometric growth in the adult phase $\left(b=0.34 ; \theta=18.8^{\circ}\right)$, with a slope reduction by $31.9^{\circ}$ when these log-regression lines were compared. This same allometric pattern was obtained for the $\mathrm{CCH}$ vs. CL ratio (Fig. 4B) in both juvenile $\left(b=1.37 ; \theta=53.9^{\circ}\right)$ and adult females $(b=0.16$; $\left.\theta=9.1^{\circ}\right)$, with a deflection of $44.8^{\circ}$ between regression slopes.

Summarizing, changes in regression slopes between development phases (see Table 1) were detected in chelar growth pattern when used invariably between length or height of carpus of $C$. major. Otherwise, in adult females these two carpal measurements showed a reduced growth pattern indicating b-values of 0.34 $(\mathrm{CCL})$ and $0.16(\mathrm{CCH})$, even with a relative growth more evident to CCL than to $\mathrm{CCH}$.

For the ratios $\mathrm{CCL}$ vs. $\mathrm{CL}$ and $\mathrm{CCH}$ vs. CL the breaking points between regression lines (juvenile and adult) were located at 14.9 and $16.3 \mathrm{~mm} \mathrm{CL}$ and at 15.0 and $16.2 \mathrm{~mm}$ CL for males and females, respectively. Synchronicity was observed among the estimated sizes, independent of the biometric variable of the chelar carpus (CCL or $\mathrm{CCH}$ ), but more pronounced in $\mathrm{CCH}$ due to the expressive difference between slopes (b-values) of the regression lines (juvenile and adult).

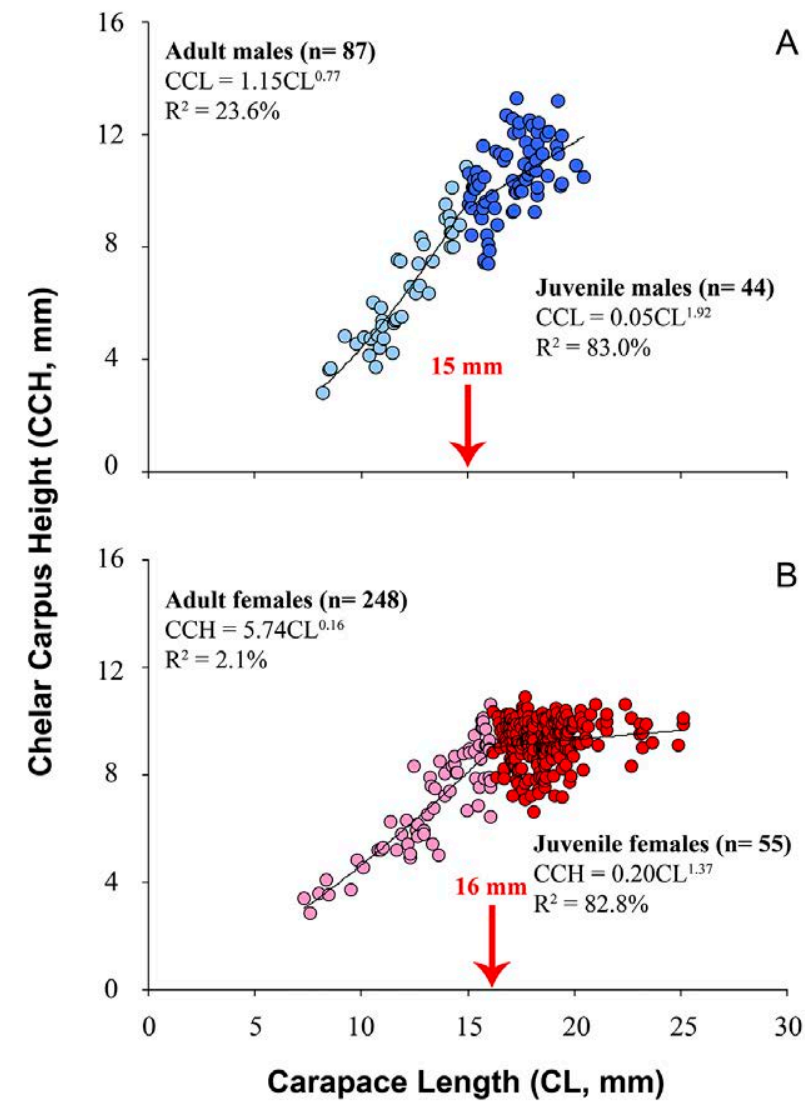

Fig. 4. - Biometric relationship $\mathrm{CCH}$ vs. $\mathrm{CL}$, regression analyses of both development phases in males (A) and females (B), and size of morphological maturity. CCL, carpus length of the major cheliped;

CL, carapace length; light points, juveniles; dark points, adults.

Table 2. - Callichirus major (Say, 1818). Handedness ratio (HR) in each sex expressed by division of the carpus length from the right by left chelipeds $(\mathrm{HR}=\mathrm{CPLR} / \mathrm{CPLL}) . \mathrm{N}$, number of individuals; \%, relative frequency; HO, homochely; LHE, left heterochely; RHE, right heterochely; Min., minimum value; Max., maximum value; $\mathrm{x}$, mean; sd, standard deviation; $\mathrm{CV}(\%)$, percentual coefficient of variation.

\begin{tabular}{lcccccc}
\hline Chelar & \multirow{2}{*}{$\mathrm{N}$} & $\%$ & Min. & Maxdedness Ratio \\
Morphotypes & & & Xax & x \pm sd & CV $(\%)$ \\
\hline Males & & & & & & \\
LHE & 54 & 41.2 & 0.47 & 0.89 & $0.64 \pm 0.11$ & 16.7 \\
HO & 17 & 13.0 & 0.92 & 1.09 & $0.99 \pm 0.05$ & 4.6 \\
RHE & 60 & 45.8 & 1.12 & 2.48 & $1.58 \pm 0.32$ & 20.0 \\
Total & 131 & 100 & 0.47 & 2.48 & $1.11 \pm 0.49$ & 44.4 \\
Females & & & & & & \\
LHE & 65 & 21.5 & 0.67 & 0.89 & $0.84 \pm 0.05$ & 6.0 \\
HO & 178 & 58.7 & 0.90 & 1.10 & $0.99 \pm 0.05$ & 5.1 \\
RHE & 60 & 19.8 & 1.11 & 1.48 & $1.21 \pm 0.09$ & 7.6 \\
Total & 303 & 100 & 0.67 & 1.48 & $1.00 \pm 0.13$ & 13.4 \\
\hline
\end{tabular}

\section{Handedness and chelar types}

Heterochely was predominant in $86.9 \%$ of the males $(13.1 \%$ were homochelous), with the inverse observation occurring in females $(59.3 \%$ homochelous and $40.7 \%$ heterochelous). There was no specific laterality for heterochely in both sexes (Table 2): males (RHE $=45.8 \%$ and $\mathrm{LHE}=41.2 \% ; \chi^{2}=0.22$; $\mathrm{P}>0.01)$; and females $(\mathrm{RHE}=19.8 \%$ and $\mathrm{LHE}=21.5 \%$; $\left.\chi^{2}=0.52 ; \mathrm{P}>0.01\right)$. In homochely, $\mathrm{CCL}$ in males $(7.7 \pm 2.2 \mathrm{~mm})$ was smaller than in females $(11.2 \pm 1.8$ 


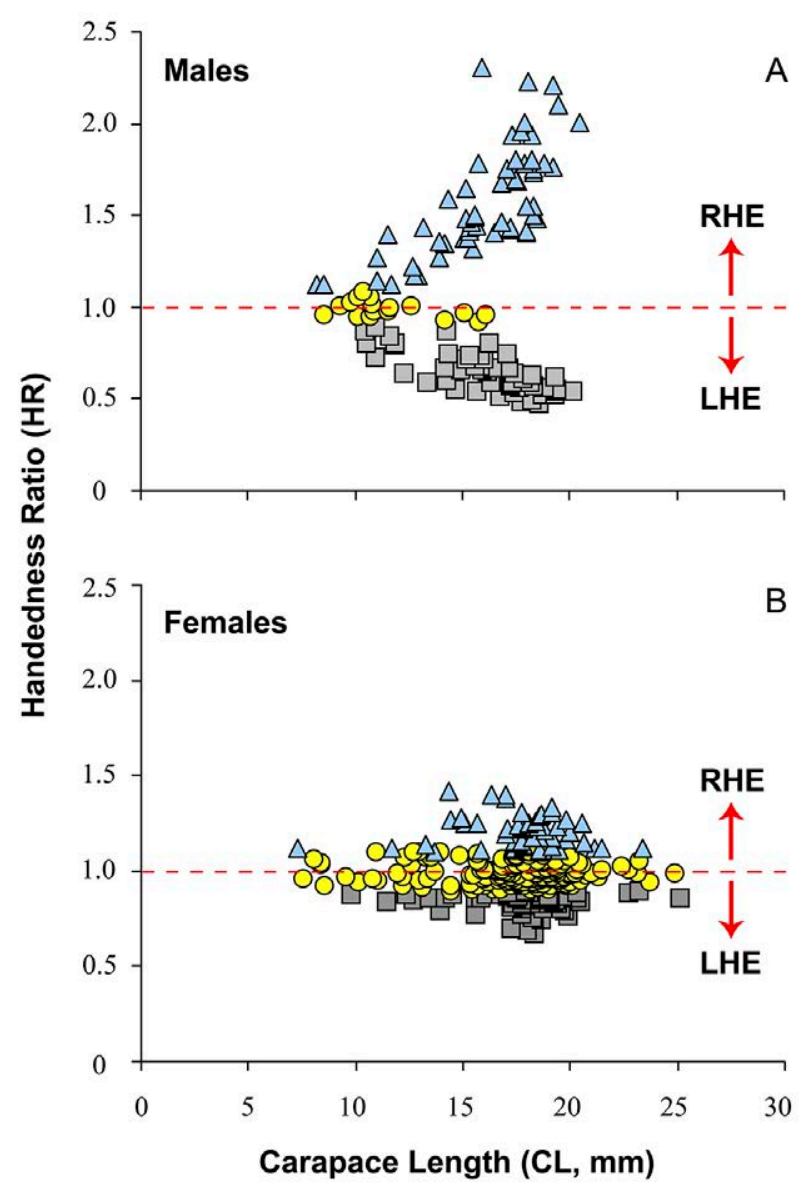

Fig. 5. - Handedness rate (HR) between chelipeds related to carapace length (CL), expressed in three chelar types in males (A) and females (B). HO, homochelous (circles); RHE, right heterochelous (triangles); and LHE, left heterochelous (squares).

$\mathrm{mm})\left(\mathrm{t}=-7.29 ; \mathrm{P}=8.4410^{-12}\right)$, a fact also occurring in males with smaller sizes ( $\mathrm{CL}<16 \mathrm{~mm} ; \mathrm{N}=17)$. The opposite occurred for heterochely, with the CCL of males $(15.2 \pm 5.4 \mathrm{~mm})$ larger than in females $(11.7 \pm 1.9 \mathrm{~mm})$ $\left(\mathrm{t}=-9.92 ; \mathrm{P}=5.3410^{-21}\right)$, but absence of expressive laterality for males (right, $16.2 \pm 4.8 \mathrm{~mm}$; left, $16.3 \pm 4.7$ $\mathrm{mm} ; \mathrm{t}=0.32 ; \mathrm{P}=0.75$ ) and females (right, $12.4 \pm 1.7 \mathrm{~mm}$; left, $12.4 \pm 1.8 \mathrm{~mm} ; \mathrm{t}=-0.85 ; \mathrm{P}=0.40)$.

Heterochely was more evident in males than females of $C$. major, with the former having a difference between chelipeds ( 34.4 to $35.7 \%$ ) twice as great as the latter (16.4 to $16.8 \%)$. Nevertheless, this finding confirmed a percentage similarity between right and left major chelipeds in each sex, confirming the absence of laterality (males, $\mathrm{t}=0.12 ; \mathrm{P}=0.91$; females, $\mathrm{t}=0.04$; $\mathrm{P}=0.97)$. In homochelous specimens this occurred at a lower percentage difference between chelipeds (males, $3.8 \pm 2.4 \%$; females, $4.3 \pm 2.7 \%$ ), with no differences between the sexes $(\mathrm{t}=-0.81 ; \mathrm{P}=0.42)$.

Our results revealed that HR did not differ in between the sexes in homochelous specimens (males, $0.99 \pm 0.05=$ females, $0.99 \pm 0.05 ; \mathrm{t}=0.35 ; \mathrm{P}=0.98$ ), while in heterochelous specimens a variation was confirmed: the major right claw (males, $1.58 \pm 0.32 \neq$ females, $\left.1.21 \pm 0.09 ; \mathrm{t}=-8.63 ; \mathrm{P}=1.5810^{-12}\right)$; and the major left claw (males, $0.64 \pm 0.11 \neq$ females, $0.84 \pm 0.05$; $\mathrm{t}=12.14$;
$\mathrm{P}=2.2010^{-16}$ ) (Table 2). This HR was also confirmed in all the size classes (CL), confirming two morphotypes (homo- and heterochelous) for C. major, regardless of sex (Fig. 5). A reduced coefficient of variation for HR was found when $\mathrm{CL}<10 \mathrm{~mm}$ (males, $7.2 \%$; females, $8.1 \%$ ), which increases this parameter in larger sizes, specifically in males $(45.0 \%)$, while in females the percentage was three times smaller (13.6\%).

$C$. major had the most evident heterochely from $10 \mathrm{~mm} \mathrm{CL}$, especially in males, with the carpus of the major cheliped showing an expressive change in the growth rate between 15 and $16 \mathrm{~mm} \mathrm{CL}$. It is possible that cheliped differentiation begins a little before the size of maturity, but it is still subtle, and exacerbated in males after the inflection point (puberty moult) that marks the ontogeny of this species.

\section{DISCUSSION}

Females of $C$. major attained a larger body size than males, thus confirming the general trend reported in other callianassid shrimps (e.g. Biffarius filholi [A. Milne-Edwards, 1878], Devine 1966; Callichirus garthi [Retamal, 1975], Hernáez and Wehrtmann 2007; Lepidophthalmus siriboia Felder and Rodrigues, 1993, Rosa-Filho et al. 2013; for exceptions, Trypaea australiensis Dana, 1852, Hailstone and Stephenson 1961). One of the few experimental studies about behaviour of ghost shrimps indicated that mating success does not depend on male size, because in these species the male does not guard the female during the sexual encounter (Somiya and Tamaki 2017). Therefore, there is no sexual selection for a large body in males of callianassid shrimps, as is likely to be the case in C. major. Moreover, small body size and one hypertrophied cheliped in males are obviously advantageous for reproduction in $C$. major given the considerable number of ovigerous females $(>40 \%)$ observed by us during several sampling months.

Aggressive interactions are common in $C$. major when two male individuals encounter each other within a gallery, so the development of larger chelipeds in species of this genus might give comparative advantages during territory defense or also during competition for sexual partners (Rodrigues and Höld 1990). In males of C. major, the growth of the cheliped carpus showed positive allometry in individuals larger than $15 \mathrm{~mm}$ CL (Figs 3A, 4A), resulting in larger ghost shrimps likely having stronger chelipeds. However, relative growth of the cheliped length in males had a positive allometric pattern in both ontogenetic phases, independent of the article considered (carpus or propodus). This pattern differed from $C$. garthi, in which the PL grew more in adults (Hernáez and Wehrtmann 2007), a fact that was unfortunately not evaluated by us or other studies on C. major (Alves-Júnior et al. 2014, 2018, Rosa et al. 2018). In females of $C$. major, the relative growth pattern did not differ between biometric relationships involving the propodus or carpus of the cheliped as a dependent variable. This fact was also reported in Lepidophthalmus louisianensis (Schmitt, 
Table 3. - Relative growth patterns ( 0 , isometry; + , positive allometry; - , negative allometry) in Callianassidae, by sex and development phases (J, juveniles; A, adults), considering carapace length (CL) as an independent variable in function of the dependent variables (CPH, carpus height; CPL, carpus length; PH, propodus height; PL, propodus length; PW, propodus width), measured in the major cheliped. A-J, difference level of allometry between adults (A) and juveniles (J); np, not possible. * Currently accepted as Callichirus garthi; ** Positive allometric growth informed for each sex, but not for each development phase.

\begin{tabular}{|c|c|c|c|c|c|c|c|c|}
\hline \multirow{2}{*}{ Species } & \multirow{2}{*}{ Author (Year) } & \multirow{2}{*}{$\begin{array}{l}\text { Biometric } \\
\text { relationships }\end{array}$} & \multicolumn{3}{|c|}{ Males } & \multicolumn{3}{|c|}{ Females } \\
\hline & & & $\mathrm{J}$ & A & A-J & $\mathrm{J}$ & A & A-J \\
\hline Callichirus garthi* & Hernáez and Wehrtmann (2007) & PL vs. CL & $0.90(-)$ & $2.32(+)$ & 1.42 & $0.90(-)$ & $0.86(-)$ & -0.04 \\
\hline \multirow[t]{4}{*}{ Callichirus major } & Rodrigues (1985) & PL vs. CL & $1.25(+)$ & $1.38(+)$ & 0.13 & $0.76(-)$ & $0.90(-)$ & 0.14 \\
\hline & Alves-Júnior et al. (2014)** & $\begin{array}{l}\text { PL vs. CL } \\
\text { CPL vs. CL }\end{array}$ & $\begin{array}{l}1.67(+) \\
2.02(+)\end{array}$ & $\begin{array}{l}1.67(+) \\
1.42(+)\end{array}$ & $\mathrm{np}_{-0.60}$ & $\begin{array}{l}1.48(+) \\
1.22(+)\end{array}$ & $\begin{array}{l}1.48(+) \\
0.34(-)\end{array}$ & $\mathrm{np}_{-0.88}$ \\
\hline & Alves-Júnior et al. (2018)** & PL vs. CL & $2.14(+)$ & $2.14(+)$ & np & $1.36(+)$ & $1.36(+)$ & $\mathrm{np}$ \\
\hline & Present study & CPH vs. CL & $1.92(+)$ & $0.77(-)$ & -1.15 & $1.37(+)$ & $0.16(-)$ & -1.21 \\
\hline Callichirus seilacheri & Hernáez and João (2018) & CPL vs. CL & $1.07(0)$ & $1.61(+)$ & 0.54 & $0.96(0)$ & $0.92(0)$ & -0.04 \\
\hline Lepidophthalmus louisianensis & Felder and Lovett (1989) & $\begin{array}{l}\text { PW vs. CL } \\
\text { PH vs. CL }\end{array}$ & $\begin{array}{l}1.64(+) \\
1.36(+)\end{array}$ & $\begin{array}{l}1.35(+) \\
1.17(+)\end{array}$ & $\begin{array}{l}-0.29 \\
-0.19\end{array}$ & $\begin{array}{l}1.90(+) \\
1.46(+)\end{array}$ & $\begin{array}{l}0.61(-) \\
0.70(-)\end{array}$ & $\begin{array}{l}-1.29 \\
-0.76\end{array}$ \\
\hline Lepidophthalmus sinuensis & Nates and Felder (1999) & $\begin{array}{l}\text { PW vs. CL } \\
\text { PH vs. CL }\end{array}$ & $\begin{array}{l}1.53(+) \\
1.44(+)\end{array}$ & $\begin{array}{l}1.61(+) \\
1.48(+)\end{array}$ & $\begin{array}{l}0.08 \\
0.04\end{array}$ & $\begin{array}{l}1.63(+) \\
1.47(+)\end{array}$ & $\begin{array}{l}0.44(-) \\
0.49(-)\end{array}$ & $\begin{array}{l}-1.19 \\
-0.98\end{array}$ \\
\hline
\end{tabular}

1935) and Lepidophthalmus sinuensis Lemaitre and Rodrigues, 1991 (Table 3), and has been associated with the fact that female callianassids usually invest less energy in chelar growth than males (Hernáez and João 2018), because the reproductive success of females depends on reaching a larger body size and not larger chelipeds (see Bauer 2004).

Biometric relationships involving variables measured from cheliped articles with higher growth can be used with success in maturity size estimates. This fact was verified in our study with chelar carpus variables of $C$. major, when compared with studies in which PL was used. A longer carpus than propodus seems to be a common character in heterochelic chelipeds of the Callichirus species previously studied (see Fig. 6). In contrast, other genera in Callianassidae have a chelar propodus that is more developed than the carpus (Manning and Felder 1991). Moreover, according to Hyzny and Muller (2010), even in other genera with an elongated carpus (e.g. Trypaea Dana, 1852 and Podocallichirus Sakai, 1999), this article has never been so developed as in the Callichirus species.

The inflection point between two straight lines represents the size of puberty moult (morphological maturity), from which juvenile and adult phases can be potentially separated (Hartnoll 1974, 1978). Our results revealed maturity sizes at $15 \mathrm{~mm}$ CL (males) and $16 \mathrm{~mm} \mathrm{CL}$ (females), which are greater than those found for C. major by Rodrigues (1985), in which PL was used as a dependent variable (11 to $14 \mathrm{~mm} \mathrm{CL}$, respectively) and by Alves-Júnior et al. 2018 (11.2 mm for males and $11.04 \mathrm{~mm}$ for females, based on major cheliped propodus length). Alternatively, we detected that male heterochely of $C$. major started from $10 \mathrm{~mm}$ CL, reinforcing the information reported previously by these authors. Furthermore, the greater difference between b-values (see Table 3: A-J $=-0.60$ to -1.15 ) was obtained with the biometric relationships involving the carpus of the cheliped, independent of the variable considered (length or height). These values were negative and smaller than those found for other callianassid species (see Table 3), which can be related to the morphological structure of Callichirus chelipeds, as observed in Figure 6.
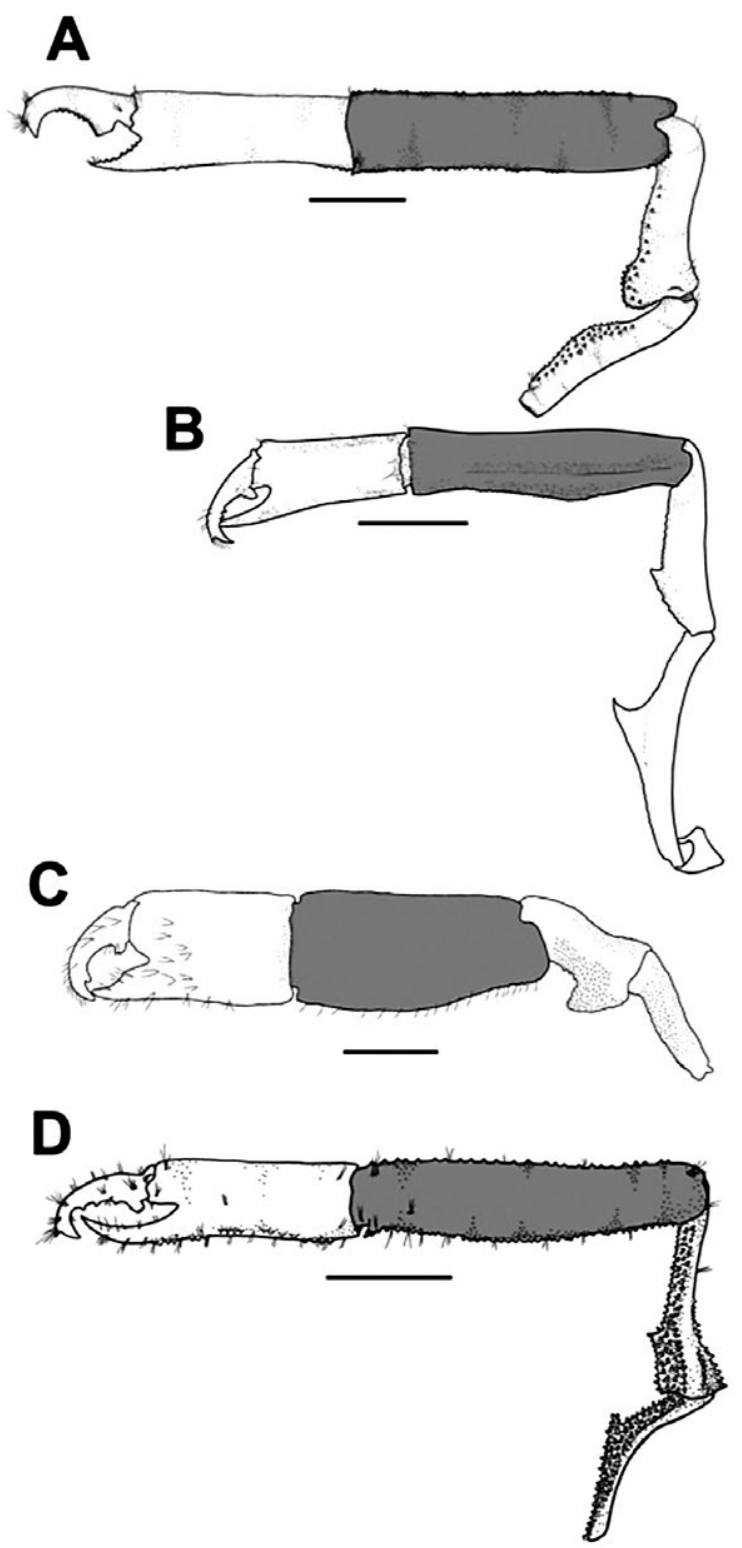

Fig. 6. - Male larger cheliped (carpus in grey) in four American species of Callichirus: A, C. garthi; B, C. islagrande; C, C. major; and D, C. seilacheri. (A, D, redrawn from Hernáez et al. 2015; B, Hernáez unpublished data; C, present study). 
Heterochelous males were common in $C$. major $(87 \%)$ from Gonzaga beach, as occurs with other species of the genus Callichirus (Manning and Felder 1986, Hernáez and Wehrtmann 2007, Hernáez et al. 2015). On the other hand, most females of $C$. major were homochelous $(59.3 \%)$. This information is also original for this species, because Manning and Felder $(1986,1991)$ indicated similar cheliped sizes in juveniles and adult females, the latter previously considered 'almost homochelous' or having a 'subtly unequal size'. Females of $C$. major had a greater mean size (CL) than males, but showed chelipeds with smaller sizes and slightly heterochelic. Furthermore, both sexes of C. major did not show laterality of the chelipeds in relation to the carpus length, which is a peculiar characteristic in Callianassidae species: e.g. Lepidophthalmus louisianensis (=Callianassa louisianensis), studied by Felder and Lovett (1989); Biffarius filholi studied by Berkenbusch and Rowden (1998); Pestarella tyrrhena (Petagna, 1792) (=Callianassa tyrrhena), according to Dworschak (1998); and Lepidophthalmus sinuensis, reported by Nates and Felder (1999).

According to Rodrigues and Höld (1990), the hypertrophied chelipeds in males of $C$. major are often used to defend galleries against invasion from other shrimps from the same or opposite sex. This information and the presence of a high frequency of heterochelous males in relation to heterochelous females suggest an intense male-male competition for sexual partners in $C$. major, and therefore offers indirect evidence of polygamy in this species. Alternatively, a low frequency of adult males in $C$. major were homochelous, which might be related to male feminization caused by hormonal production of the ovarian part of the testis. According to Souza et al. (2017), the ovarian section of the testis in adult males of $C$. major does not appear to be functional, because there are no ducts for releasing oocytes. However, the same authors mention the existence of mature oocytes in the male gonad, so it is totally possible that the ovarian section is producing hormones that feminize the individual.

Summarizing, in $C$. major the chelar growth differed according to sex and ontogenetic phases (juvenile and adults), changing with the onset of morphological maturity (15-16 mm CL), when an evident sexual dimorphism was detected (e.g. higher chelar size in males, mainly in adults). Analysis of biometric variables in callianassids, based on the carpus of the cheliped (length and height), can sometimes be more effective during the estimation of morphologic maturity size. Two morphotypes were described in this species according to their chelar sizes (homo- and heterochelous), an attribute observed in both sexes, although heterochely was more frequent (and evident) in adult males. The individuals of each sex did not show laterality of the major cheliped (handedness).

\section{ACKNOWLEDGEMENTS}

This study was supported by CAPES (Coordination of Improvement of Higher-Level Personnel, \# 1688290), which funded the master scholarship to
JPPR; by CNPq (National Council for Scientific and Technological Development, \# 303286/2016-4), for the research aid to MAAP; and by FAPESP (São Paulo State Research Foundation, \# 2015/09020-0) for the postdoctoral scholarship to $\mathrm{PH}$. The authors also thank SISBIO (Brazilian Institute of Environment and Renewable Natural Resources, \# 53567-1) for the licence granted to collect the animals; Akeme Matsunaga, Camila Pimenta and Michel Angeloni (members of CRUSTA - Research Group on Crustacean Biology) for helping with field samples, and André Pezzuol for the transportation of all material and equipment on the field trips. Finally, our special thanks are given to the anonymous reviewers, who helped improve the content and format of this manuscript.

\section{REFERENCES}

Alves-Júnior F.A., Feitosa F.A.N, Araújo M. 2014. Crescimento alométrico de Callichirus major (Say 1818) (Crustacea: Callianassidae) em uma praia arenosa do nordeste brasileiro. Trop. Oceanogr. 42: 13-21. [In Portuguese] https://doi.org/10.5914/tropocean.v42i3.5766

Alves-Júnior F.A., Santana J.L., Figueiredo A.M.F., et al. 2018. Population and reproductive biology of Callichirus major (Say, 1818) (Decapoda: Axiidae: Callianassidae) in an urban beach, Northeastern Brazil. Pan-Am. J. Aquat. Sci. 13: 166-178.

Bauer R.T. 2004. Remarkable shrimps. Norman OK: Oklahoma University Press. 282 pages.

Berkenbusch K., Rowden A.A. 1998. Population dynamics of the burrowing ghost shrimp Callianassa filholi on an intertidal sandflat in New Zealand (Decapoda: Thalassinidea). Ophelia 49: $55-69$

https://doi.org/10.1080/00785326.1998.10409373

Bueno S.L.S., Shimizu R.M. 2009. Allometric growth, sexual maturity, and adult male chelae dimorphism in Aegla franca (Decapoda: Anomura: Aeglidae). J. Crustac. Biol. 29: 317-328. https://doi.org/10.1651/07-2973.1

Davanso T.M., Taddei F.G., Hirose G.L., et al. 2016. Sexual maturity, handedness and sexual dimorphism of the freshwater crab Dilocarcinus pagei in south eastern Brazil. Bol. Inst. Pesca 42: 269-279. https://doi.org/10.20950/1678-2305.2016v42n2p269

Devine C.E. 1966. Ecology of Callianassa filholi Milne-Edwards, 1878 (Crustacea, Thalassinidea). T. Roy. Soc. Nz. 8: 93-110.

Dworschak P.C. 1998. Observations on the biology of the burrowing mud shrimps Callianassa tyrrhena and C. candida (Decapoda: Thalassinidea). J. Nat. Hist. 32: 1535-1548. https://doi.org/10.1080/00222939800771071

Felder D.L. 2001. Diversity and ecological significance of deepburrowing macrocrustaceans in coastal tropical waters of Americas (Decapoda: Thalassinidea). Interciencia 26: 440-449.

Felder D.L., Lovett D.L. 1989. Relative growth and sexual maturation in the estuarine ghost shrimp Callianassa louisianensis Schmitt, 1935. J. Crustac. Biol. 9: 540-553. https://doi.org/10.1163/193724089X00566

Hailstone T.S., Stephenson W. 1961. The biology of Callianassa (Trypaea) australiensis Dana, 1852 (Crustacea, Thalassinidea). Univ. Queensl. Pap. 1: 259-285.

Hartnoll R.G. 1974. Variation in growth pattern between some secondary sexual characters in crabs (Decapoda, Brachyura). Crustaceana 27: 151-156. https://doi.org/10.1163/156854074X00334

Hartnoll R.G. 1978. The determination of relative growth in Crustacea. Crustaceana 34: 281-293. https://doi.org/10.1163/156854078X00844

Hartnoll R.G. 1982. Growth. In: Abele L.G. (ed), The biology of Crustacea - Embryology, Morphology and Genetics. Academic Press, New York, pp. 111-196.

Hartnoll R.G. 2012. Relative growth: description and analysis. In: Schram F.R., von Vaupel Klein J.C. (eds), Treatise on Zoology - Anatomy, Taxonomy, Biology. The Crustacea. Brill, Leiden, pp. $365-401$. https://doi.org/10.1163/9789004188259 008

Hay W.P., Shore C.A. 1918. The decapod crustaceans of Beaufort, 
N.C., and the surrounding region. Bull. U.S. Bur. Fish. 35: 371-475.

https://www.st.nmfs.noaa.gov/spo/FishBull/35-1/hay.pdf

Hernáez P. 2018. An update on reproduction in ghost shrimps (Decapoda: Axiidea) and mud lobsters (Decapoda: Gebiidea). In: Türkoğlu M., Önal U, Ismen A., Marine Ecology, IntechOpen, pp. 231-253.

Hernáez P., João M.C.A. 2018. Social structure, sexual dimorphism and relative growth in the ghost shrimp Callichirus seilacheri (Bott, 1955) (Decapoda, Axiidea, Callianassidae) from the tropical Eastern Pacific. Mar. Biol. Res. 14: 856-867. https://doi.org/10.1080/17451000.2018.1529415

Hernáez P., Wehrtmann I.S. 2007. Population biology of the burrowing shrimp Callichirus seilacheri (Decapoda: Callianassidae) in northern Chile. Rev. Biol. Trop. 55: 141-152.

Hernáez P., Gamboa-González A., De Grave S. 2015. Callichirus garthi is a valid species, distinct from C. seilacheri (Decapoda: Axiidea: Callianassidae). Mar. Biol. Res. 11: 990-997. https://doi.org/10.1080/17451000.2015.1044999

Hernáez P., Granda-Rodríguez H., Rio J.P.P., et al. 2018. Morphological remarks in the ghost shrimp Callichirus seilacheri (Bott, 1955) (Decapoda, Callianassidae). Bol. Inst. Pesca 44: 91-99. https://doi.org/10.20950/1678-2305.2018.287

Hernáez P., Hereman M.J., Pimenta C.E.R., et al. 2019. La efectividad de una ley de protección al servicio de la conservación de un recurso marino: El ejemplo del camarón fantasma Callichirus major (Decapoda, Callianassidae) de la costa de Brasil. Iheringia 109: 1-9. https://doi.org/10.1590/1678-4766e2019001

Huxley J.S. 1950. Relative growth and form transformation. Proc. Zool. Soc. Lond. 137: 465-469.

Hyzny M., Muller P.M. 2010. The first fossil record of the genus Callichirus (Decapoda, Axiidea, Callianassidae) from the middle Miocene of Hungary, with description of a new species. Bull. Mizunami Fossil Mus. 36: 37-43.

Laitano M.V., Farias N.E., Cledón M. 2013. Prey preference of the stone crab Platyxanthus crenulatus (Decapoda: Platyxanthidae) in laboratory conditions. Nauplius 21: 17-23. https://doi.org/10.1590/S0104-64972013000100003

Manning R.B., Felder D.L. 1986. The status of the callianassid genus Callichirus Stimpson, 1866 (Crustacea: Decapoda: Thalassinidea). P. Biol. Soc. Wash. 99: 437-443.

Manning R.B., Felder D.L. 1991. Revision of the American Callianassidae (Crustacea: Decapoda: Thalassinidea). P. Biol. Soc. Wash. 104: 764-792.

Mariappan P., Balasundaram C., Schmitz B. 2000. Decapod crustacean chelipeds: an overview. J. Biosci. 25: 301-313. https://doi.org/10.1007/BF02703939

Melo G.A.S. 1999. Manual de identificação dos Crustacea Decapoda do litoral brasileiro: Anomura, Thalassinidea, Palinuridea e Astacidea. Editora Plêiade/FAPESP, São Paulo, 551 pp. [In Portuguese]

Nates S.F., Felder D.L. 1999. Growth and maturation of the ghost shrimp Lepidophthalmus sinuensis Lemaitre and Rodrigues, 1991 (Crustacea, Decapoda, Callianassidae), a burrowing pest in penaeid shrimp culture ponds. Fish. Bull. 97: 526-541.

Pardal-Souza A.L., Pinheiro M.A.A. 2013. Relative growth and reproduction in Achelous spinicarpus (Crustacea: Portunidae) on the south-eastern continental shelf of Brazil. J. Mar. Biol. Assoc. U.K. 93: 667-674. https://doi.org/10.1017/S0025315412000318

Pescinelli R.A., Almeida A.O., Costa R.C. 2018. Population structure, relative growth and morphological sexual maturity of the snapping shrimp Alpheus brasileiro Anker, 2012 (Caridea: Alpheidae) from the south-eastern coast of Brazil. Mar. Biol. Res. 14: 610-620 https://doi.org/10.1080/17451000.2018.1472383

Pinheiro M.A.A., Fransozo A. 1998. Sexual maturity of the speckled swimming crab Arenaeus cribrarius (Lamarck, 1818) (Decapoda: Brachyura: Portunidae), in the Ubatuba litoral, São Paulo State, Brazil. Crustaceana 71: 434-452. https://doi.org/10.1163/156854098X00536

R Core Team. 2013. R: A language and environment for statistical computing. Vienna, R Foundation for Statistical Computing. Access in: 12/07/2017. http://www.R-project.org

Rio J.P.P. 2018. Taxonomia, morfologia reprodutiva e crescimento relativo no camarão-fantasma Callichirus major (Say, 1818) (Decapoda: Callianassidae), no sudeste do Brasil. M.Sc thesis, Instituto de Biociências do Litoral Paulista, Universidade Estadual Paulista, 91 pp. [In Portuguese]

Rodrigues S.A. 1971. Mud shrimps of the genus Callianassa Leach from the Brazilian coast (Crustacea, Decapoda). Arq. Zool. 20: 191-223. https://doi.org/10.11606/issn.2176-7793.v20i3p191-223

Rodrigues S.A. 1976. Sobre a reprodução, embriologia e desenvolvimento larval de Callichirus major Say, 1818 (Crustacea, Decapoda Thalassinidea). Bol. Zool. 1: 85-104. [In Portuguese] https://doi.org/10.11606/issn.2526-3358.bolzoo.1976.121560

Rodrigues S.A. 1985. Sobre o crescimento relativo de Callichirus major (Say, 1818) (Crustacea, Decapoda, Thalassinidea). Bol. Zool. 9: 195-211. [In Portuguese] https://doi. org/10.11606/issn. 2526-3358.bolzoo.1985.122297

Rodrigues S.A., Hödl W. 1990. Burrowing behaviour in the ghost shrimps Callichirus major and C. mirim. Wiss. Film. 41: 48-58.

Rodrigues S.A., Shimizu R.M. 1997. Autoecologia de Callichirus major (Say, 1818). Oecol. Austral. 3: 155-170. [In Portuguese] https://doi.org/10.4257/oeco.1997.0301.10

Rosa-Filho J.S., Girard T.C., Frédou F.L. 2013. Population dynamics of the burrowing shrimp Lepidophthalmus siriboia Felder and Rodrigues, 1993 (Reptantia: Axiidea: Callianassidae) on the Amazonian coast. J. Crustac. Biol. 33: 503-511. https://doi.org/10.1163/1937240X-00002157

Rosa L.C., Freire K.M.F, Souza M.J.M. 2018. Spatial distribution and population dynamics of Callichirus major (Crustacea, Callianassidae) in a tropical sandy beach, northeastern Brazil. Invertebr. Biol. 137: 308-318. https://doi.org/10.1111/ivb.12228

Sokal R.R., Rohlf T.J. 2003. Biometry: the principles and practice of statistics in biological research. Freeman, New York.

Somerton D.A. 1980. A computer technique for estimating the size of sexual maturity in crabs. Can. J. Fish. Aquat. Sci. 37: 1488-1494. https://doi.org/10.1139/f80-192

Somerton D.A., Macintosh R.A. 1983. The size at sexual maturity of blue king crab, Paralithodes platypus, in Alaska. Fish. Bull. 81: 621-628.

Somiya R., Tamaki A. 2017. Unraveling mating behavior for Axiidea (Crustacea: Decapoda): burrow-dwelling callinassid shrimp in intertidal sandflat. J. Exp. Mar. Biol. Ecol. 486: 305-313. https://doi.org/10.1016/j.jembe.2016.09.019

Souza J.R.B., Borzone C.A. 2003. A extracão de corrupto, Callichirus major (Say) (Crustacea, Thalassinidea), para uso como isca em praias do litoral do Paraná: as populações exploradas. Rev. Bras. Zool. 20: 625-630. [In Portuguese] https://doi.org/10.1590/S0101-81752003000400011

Souza T.L., Braga A.A., López-Greco L.S., et al. 2017. Functional morphology of the male reproductive system in Callichirus major (Crustacea: Decapoda: Axiidea): Evidence of oocytes in the gonad. Acta Zool. 119: 1-10. 